\title{
Suppression, denial, sublimation: Defending against the initial pains of very long life
} sentences.

\begin{abstract}
The central purpose of the article is to explore the psychic components of the early pains of imprisonment described by male and female prisoners serving very long mandatory life sentences for murder. While there is a strong tradition of documenting prisoners' adaptations to 'life inside', little work in prisons sociology explores how life-sentenced prisoners, specifically those convicted of murder, reactively respond and adjust to the early years of these sentences. Having outlined prisoners' descriptions of entry shock, temporal vertigo and intrusive recollections, we draw upon a Freudian terminology of 'defence mechanisms of the ego' to argue that suppression, denial, and sublimation represent key ways of 'defending against' (rather than 'adapting to') these experiences. We suggest that the particular offence-time nexus of our sample - the specific offence of murder combined with a very long sentence - helps to explain these defensive patterns.
\end{abstract}


Since the 1980s, concerns have been raised about managing growing numbers of 'long-term' offenders in American and British prisons, and a lack of 'cognizance' regarding the effects of such periods of confinement (e.g. MacKenzie \& Goodstein, 1985; Bottoms \& Light, 1987). In England and Wales, the long-term life-sentenced prison population has experienced large and rapid increases over this period, particularly for individuals sentenced in young adulthood; ${ }^{1}$ for instance, while 'life' once meant serving an average of nine years in prison (cf. Cohen \& Taylor, 1972), the minimum length of time being served under such sentences has increased dramatically in recent years, from 12.5 years in 2003 to 21.1 years in $2013 .^{2}$ Ergo, a growing number of prisoners are serving sentences that were almost unheard of a generation ago sentences where the 'rupture in life trajectories' induced by incarceration (cf. Mathiassen, 2016: 4) is more extreme than the majority of sentenced prisoners - and in conditions about which very little is known.

This article reports findings from a wider study examining the experiences of men and women serving very long mandatory life-sentences (minimum tariffs of 15 years or more) for murder received when aged 25 or under. Its particular focus is on their reaction to the early years of their sentence, a period during which problems of imprisonment were reported as particularly 'severe' (see Hulley, Crewe \& Wright, 2015). Of key interest is, firstly, the specific pains of imprisonment that characterised the early phase of confinement for those within our sample, namely: entry shock, temporal vertigo, and intrusive recollections. Having outlined these experiences, we explore our second point of interest - that is, the ways in which participants coped with, responded to, and 'defended against' these initial pains. In doing so, and having found existing frameworks incapable of accounting for our participants' preoccupations, we have turned to Freudian terminology of suppression, denial, and sublimation to account for the processes of psychic defending that our participants described. Our overall argument is that these patterns of experience and adjustment reflect a specific Offence-Time Nexus; that is, we suggest that these defensive patterns represent a specific response to: i) the offence of murder; and ii) the temporal conditions of exceptionally long 'life' sentences.

\footnotetext{
${ }^{1}$ Information obtained from Ministry of Justice by Dr Susie Hulley, Institute of Criminology, University of Cambridge - Freedom of Information request FOI/68152, December 2010.

${ }^{2}$ Information obtained from Ministry of Justice by Jonathan Bild, Faculty of Law, University of Cambridge -

Freedom of Information request FOI/89346, April 2014.
} 


\section{The pains of long-term and life imprisonment}

I remember all too well the struggle to find a reason to get out of my prison bed in the morning. In the beginning, for 23 hours a day, all I had was a bed, a table, a chair and [...] a toilet. The future was just a long, dark tunnel.

(James, 2013, para. 3)

Within the long and venerable tradition relating to the 'pains of imprisonment' there is a smaller body of research examining the specific difficulties experienced by the long-term prisoner $^{3}$ - a field which flourished in the second half of the $20^{\text {th }}$ century, and debated the degree to which individuals incarcerated for extended periods of time experienced mental, emotional, and intellectual 'deterioration' (e.g. Cohen \& Taylor, 1972; Sapsford, 1978; Banister, Smith, Heskin, \& Bolton, 1973; Richards, 1978; Flanagan, 1981).

Liebling and Maruna (2005:3) argue that, in recent years, prisons sociologists have 'not taken seriously enough' the damaging effects of imprisonment. For those experiencing longterm exposure to the 'internal chaos, disorganization, stress, and fear' inherent in imprisonment (Haney, 2001, para. 31), the consequences are 'analogous to the acute reactions of trauma victims', including: insomnia, anxiety, panic, withdrawal, loss of control, aggression, rage, hopelessness, lethargy, depression, emotional breakdowns, and self-mutilation (Haney \& Lynch, 1997:529). This uniquely harmful 'assault on the self' inflicted on the long-term prisoner (Flanagan, 1981:211) must be endured alongside the 'petty humiliations and daily injustices' which form the backbone of any prison term (cf. Liebling \& Maruna, 2005:3). This experience may be all the more 'cruel and deprived' for women (MacKenzie, Robinson, \& Campbell, 1989:224), or those faced with the 'loss', 'liminality', and 'social death' of the life sentence (cf. Jewkes, 2005).

Further, these psychological harms of imprisonment extend beyond the prison gates. Lengthy terms in prison 'create habits of thinking and acting that can be dysfunctional' 'hypervigilance, interpersonal distrust, and suspicion', for example - which represent a 'significant impediment' to post-prison adjustment (Haney, 2001, para.38). Such harms may be

\footnotetext{
3 Long-term imprisonment lacks a singular definition, varying across time and place. In England and Wales, the Ministry of Justice (2013) recently defined 'long-term' as 'four years or more, including life sentences', and most definitions of 'long-term' prisoner fall somewhere between four and 10 years (e.g. MacKenzie \& Goodstein, 1985; Zamble \& Porporino, 1988; MacKenzie, Robinson \& Campbell, 1989). Such definitions are unlikely to capture the experience of the 21 st-century long-term 'lifer', who can now expect to serve an average minimum of 21 years. For purposes of the current study - and therefore, for this paper - a 'long-term' indeterminate prison sentence is defined as a minimum tariff of 15 years or more.
} 
irreversible. For women in particular, the pains of long-term incarceration may be exacerbated by the constraints it places on motherhood, 'forcibly suspend[ing] or even terminat[ing]' the possibility of becoming mothers at all (Jewkes, 2005:369; Jose-Kampfner, 1990; Walker \& Worrall, 2000).

Of particular and long-standing concern in much of this literature is the 'astounding' absence of knowledge (Wormith, 1984:427) related to the 'lasting effects' on the human personality of long-term imprisonment (Home Office, 1968), as well as the 'significant unresolved questions' which abound in relation to the post-release re-entry of such individuals to the outisde world (Jose-Kampfner, 1990:122). Our particular concern in this article, however, is the early phase of the very long sentence. Recent studies have challenged $a$ priori suppositions of early prisons sociologists in relation to the 'curvilinear' impact of incarceration (i.e. the assumption of problems 'increasing with length of time in custody') (Liebling \& Maruna, 2005:12), re-focusing academic interest on the initial stages of imprisonment and the intense 'psychological discomfort' generated during this time (Zamble, 1992:420). Mackenzie and Goodstein $(1985: 395,409)$ attribute the particularly 'traumatiz[ing]' nature of the early stages of long sentences to the absence of 'light at the end of the tunnel', while James (2013) idenitifes this period as presenting a basic existential challenge to the will to survive. Such sentiments are also borne out in data identifying prisoners serving very long/life sentences as presenting a particularly high risk of suicide (Liebling, 1999:302).

\section{Responding to the pains of early-stage imprisonment}

While the prison environment 'presents extraordinary adaptive problems' (Irwin, 1987/1970:67), a wealth of studies within the field of prison sociology testify to the capacity of prisoners to adjust to a world that is typically unfamiliar, intimidating and painful (Crewe, 2009:149). Early research into prison adjustment tended to identify the 'social roles' adopted to 'reduce the rigours of prison life' (Sykes, 1958/2007:107), or highlighted the forms of criminal identity which mapped onto particular prisoner orientations (Irwin, 1987/1970). Crewe (2009) identifies an important semantic consideration here - that is, adaptive styles can be identified as nouns (types of prisoner), or as verbs (forms of behaviour). While both Sykes and Irwin fall within the former - as does Crewe's own typology - other studies emphasise the latter, for example Zamble and Porporino's (1988) model of low-level, high-level, and reactive problemoriented coping, and Toch and Adams' (1989) five-fold classification of maladaptation to 
imprisonment (gratifying impulses; seeking refuge; enhancing esteem; pursuing autonomy; and maintain sanity). This distinction is important because it provides an anchor for locating the current article within the relevant literature - as an example of the latter - and for identifying our own analysis as one that is focused not on individual pathologies but on the processes and 'group behavioral patterns' (Toch \& Adams, 1989:128) of those psychically defending against very long term imprisonment for murder from a young age.

For our purposes, existing 'adaptive' frameworks are unsuitable due to three key features of our population: first, the specific 'pains' that relate to their particular offence (murder); second, the extraordinarily long indeterminate sentences they are facing; and third, the inclusion within our sample of female prisoners, whose experiences are rarely represented in adaptive classifications (cf. Hartnagel \& Gillan, 1980; though see Heffernan, 1972 for an exception). Moreover, we argue that the language of 'defending against' these pains more accurately represents their experiences in the initial years of such lengthy sentences, reflecting the essentially 'reactive' rather than 'proactive' nature of these responses.

In attempting to revise and extend the literature on patterns of 'adaptation' among such prisoners - and in recognition of the particular psychological demands of adjusting to a murder conviction and of receiving a sentence of extraordinary length - we draw on the Freudian concept of 'defence mechanisms of the ego'. Developed by Sigmund Freud in the early $20^{\text {th }}$ century, the notion of discrete 'mechanisms of defence' originally related to the quest to understand unconscious processes by which 'the ego' - that is, the self - protects 'against painful or unendurable ideas or affects [i.e. emotions]' (Freud, 1937/1992:42). While such ideas - and in particular their unconscious nature - suffered extensive criticism, more recent psychoanalytical, psychological, and even sociological, research demonstrates a 'renewed interest' in the concept (Cramer, 2000:637). One key area of study is the protective potential of such 'defence mechanisms' for individuals undergoing particularly painful or traumatic experiences. Given the longstanding interest within prison sociology in the way that prisoners seek to 'defend against' the various assaults on the 'self' posed by incarceration, the use of such concepts to help interpret their responses - particularly when described in primarily reactive terms - seems long overdue.

\section{The current study}

The study on which this article is based focused on men and women serving very long indeterminate sentences (i.e. with a minimum/‘tariff' period of 15 years or more) received 
when aged 25 years and under. All had been convicted of murder within the criminal justice system of England and Wales, and were serving mandatory life sentences.

The focus on this specific group was born out of a concern with the increasing number of prisoners serving very long sentences, and the absence of research on the experiences and consequences of such disposals, both for offenders themselves and for those who manage them. Data provided by the National Offender Management Service at the start of the fieldwork period, in February 2013, reported that there were 808 prisoners in prisons in England and Wales who matched the research criteria, held across 73 prison establishments. In total, 309 men (39\% of the male population who matched the research criteria) and 23 women (79\% of the female population who matched the research criteria) participated in the study, either by conducting an in-depth interview, completing a survey, ${ }^{4}$ or both. ${ }^{5}$

\section{Research Setting, Sample, and Method}

146 interviews ( $n=21$ women and $n=125$ men) were conducted in 25 different prisons (sixteen men's prisons and nine women's prisons) within the England and Wales prison system. Establishments visited covered all five security categories (High Security, Category B, Category C, and Open prisons), and included both adult and Young Offender Institutions. It is of particular relevance to this paper that all of the women and men interviewed had been convicted of murder and had received a mandatory life sentence.

Male interviewees were selected based on a purposive sampling procedure designed to capture prisoners at different stages of these very long sentences, defined as follows: Early less than 4 years served; Mid - the mid-point of the tariff, plus or minus 2 years; Late - tariff end date minus 2 years onwards. This aspect of the research design was based on an assumption that modes of adaptation change over time (cf. Clemmer, 1940/1958) and therefore our ambition was to explore the ways in which different stages of the sentence present different challenges for the long-term prisoner (while acknowledging the potential for cohort and period effects within this; see Crewe, Hulley \& Wright, under review).

\footnotetext{
${ }^{4}$ For further information relating to the design, implementation, and results of the survey see the paper by Hulley, Crewe \& Wright (2015), which reports exclusively on this.

${ }^{5}$ The breakdown of individuals involved in completing a survey, an interview, or both, is as follows: $n=294$ men and $n=21$ women men conducted surveys; $n=126$ men and $n=21$ women took part in interviews. Of these, 112 men and 3 women only completed a survey (and did not participate in an interview), while 183 men and 5 women only took part in an interview (and did not complete a survey).
} 
Due to the relatively low numbers of women serving very long life sentences from young adulthood at the time of our fieldwork (29 overall within the nationwide population, not all of whom took part in our study) we sought to interview all those who met our research criteria, regardless of sentence stage (in fact, only two of our interviewees did not fall within one of our pre-designated sentence stages - these are represented in the Other category in the table below).

Details of the overall interview sample, which represented nearly one fifth of the total population in which we were interested, are shown below in Table 1:

\section{INSERT TABLE 1, centred}

Interviews were conducted in two parts. The first was a detailed life history interview, which drew on the literature on narrative inquiry and life stories (e.g. Hollway \& Jefferson, 2000; McAdams, 1988) and focused on pre-sentence life (e.g. familial relationships, life aspirations, and experiences of education, authority, criminal justice and state regulation). The second part of each interview focussed on life inside prison, exploring: particular problems faced by prisoners serving such sentences; how they sought to psychologically manage the sentence; thoughts on identity, change and future; social adaptations (specifically, relationships with other prisoners and staff); and thoughts on the legitimacy of their predicament (both the conviction and the sentence). Our questions included: 'Thinking back now, can you tell me how you felt when you were first given this sentence?', 'How has being a long-term prisoner changed you as a person?', 'What have you found to be the three most difficult things about serving your sentence?', and 'How hopeful are you generally about your future?'

All interviews were transcribed and coded in full. The data was subjected to an iterative analytic approach, by which we mean 'visiting and revisiting the data', and moving between forms of inductive and deductive reasoning, in order to refine understanding (Srivastava \& Hopwood, 2009: 77). In practice, this meant noting down key themes and ideas as we read the interview transcripts, based both on relevant literature and emerging issues, discussing our thinking collectively, returning to the data to check whether our ideas held weight, and refining these ideas until we were satisfied that they provided an account that was both faithful to the data and informed by relevant theory and concepts.

\section{The initial pains of long-term confinement from young adulthood}

While some experiences recounted by interviewees could be interpreted within existing frameworks of the 'pains of imprisonment', the emotional and psychological content of the 
interviews went far beyond those standard 'pains' that typically feature within the research literature. This was particularly so when describing the early stages of the sentence, specifically, forms of entry shock, temporal vertigo, and intrusive recollections. In outlining these experiences, we seek to emphasise the way in which they were informed by what we are calling the offence-time nexus: that is, the interplay between the extreme nature of both the sentence length, and of the irremediable nature of the offence of murder for which interviewees had been convicted. While notable - and important - differences existed between our male and female participants (as we discuss further in Crewe, Hulley \& Wright, in progress), the strategies described below were broadly relevant across boundaries of gender, ethnicity, and other such variables. That is, the ways in which participants 'survived' their predicament were remarkably similar.

\section{'Entry shock'}

Narratives of numbness and shock, and themes of darkness, illusion and hopelessness, dominated interviewees' accounts of the initial period of imprisonment following conviction and sentencing. Many described the experience as 'unreal', as they struggled to process the events they were experiencing:

I spent the first month in complete shock and I thought I would wake up and go home. It wasn't real [...] And it hurt - it felt like somebody was ripping my chest open. I saw no future, no point to tomorrow. It was the darkest time of my life [...] Because there was no going back - there was no changing this; there was no undoing it or fixing it, or making it better. And suddenly everything is ripped away from you, and feels like it's been taken to a different planet.

Maria, early twenties, 20+ years' tariff, Early ${ }^{6}$

Others described a state of emotional and experiential numbness, akin to the 'dissociation' - a 'disengagement between self and environment' - evident in the criteria for post-traumatic stress disorder (cf. Feeny et al, 2000:491).

\footnotetext{
${ }^{6}$ All names referred to are pseudonyms. Quotes are accompanied by an interviewee identifier, which includes interviewee pseudonym, age, tariff length and sentence stage (as explained above). Interviewee anonymity is paramount. Therefore where detailed descriptions of events, personal circumstances, or sentences risk rendering interviewees identifiable - especially among the smaller population of women where this is more likely identifiers may be shortened, modified so as to increase opacity, or certain items omitted.
} 
In the early days following the verdict, it felt like an out-of-body experience almost. I was... I didn't feel like the steps I was taking were my own. I felt completely numbed.

Dan, late twenties, 15-year tariff, Early

Thinking back like to the first days and weeks once you'd been sentenced - can you remember how you felt at that time?

[It] felt like I was walking around in the clouds? It's hard to describe, but I think from the shock? Yeah, I felt a bit numb [...] 1 was walking around in like a dream state. A sad dream state.

Karen, late twenties, 20-year tariff, Mid

Such sentiments of numbness and dissociation were expressed with comparatively more intensity, and appeared to last longer, among the women we interviewed, supporting JoseKampfner's (1990) findings that, when sentenced, female prisoners experience an extended period of 'grief'. Entry shock was also more intense for those who had admitted guilt. Similar to the homicide perpetrators in Adshead, Ferrito and Bose's (2015:72-3) study, these men and women were weighed down by the 'horror' and 'irrevocability' of their own extreme actions. This was particularly acute for those who had killed someone they knew well or loved:

When I first came in my head was all over the place, like. I'd just killed my mate.

Blake, early twenties, 21-year tariff, Early

I just completely lost myself again [after being sentenced], and I was just like really in on myself. I was just grieving for my boyfriend. I was missing him and it was horrible [...] My head was properly twatted.

Liz, early twenties, 15-year tariff, Early

In such cases, it was almost impossible to disentangle the degree to which entry shock emanated from the conviction and sentence as from the act of killing itself.

\section{'Temporal vertigo' and time-based anxieties}

I began my long-term confinement in my early 20's, but would not breathe the fresh air of freedom until I was well into my 60 's. At 20 years of age, it is difficult to imagine 
being 30. It is much more difficult for a 20 year-old prisoner to realize that release from prison will not come until several decades pass [...] Such a long sentence did not seem real. How could it? The sentence was nearly twice as long as I had been alive on the planet.

(Santos, 1995:37-38) (emphasis added)

Time is the essence of sentencing and imprisonment, and - as suggested above - the sheer burden of the time that lay ahead in prison weighed extremely heavily on the minds of interviewees. Those who were in, or were recalling, the early phases of their sentence often noted the difficulty of coming to terms with the fact that they would be imprisoned for more years than they had been alive, or at least, had been conscious of their own existence. Such descriptions often conveyed a sense of temporal vertigo - an overwhelming feeling of dizziness, resulting from the sense that time was warping and falling away. One interviewee talked of 'his future flashing before his eyes', highlighting this sense that ontological ground was disintegrating around him. To quote another:

I was 19, when I got sentenced. Basically, all them years I've just done, growing up, I've got to do them again in prison, and it's like, 'Whoa!' I just didn't want to think about it cos I knew if I thought about it a lot then it would just mess up my head.

Curtis, late twenties, 19-year tariff, Mid

The importance of the combination of age when sentenced and sentence length on the 'temporal parameters of pain' is emphasised by O'Donnell's (2014:202) concept of the Pain Quotient, which takes account of the time left to be served and time left to be lived. As the former eclipses the latter, O'Donnell suggests, the challenge of 'making sense of prison time' intensifies. Indeed, interviewees in our study consistently talked about their struggle to 'get their head around' the length of their sentence. To do so required a temporal coping framework that (initially at least) most simply did not have; that is, they had no cognitive blueprint for 'making sense' of the length of the sentence they had been given, and its consequences, because such an event was beyond the reach of their experience and imagination:

I had no concept of 18 years of life. You know what I mean? [Five years in] I think really I've only just got my head around it. 
Hugo, early twenties, 18-year tariff, Early

You cannot comprehend it [...] You say the first few days and weeks?! It's nothing to do with the first few days - it's the first few years. It takes two, three, four, five years before you start to get your head around the sentence you're doing, that type of sentence.

Neil, early thirties 18-year tariff, Mid

Interviewees in this early stage were generally unable to articulate their thoughts in relation to the remote future (see O'Donnell 2014:203). Few could contemplate what their life might look like in half a decade, let alone the world they would inhabit on release:

And can you imagine your life five years from now? [...] Can you imagine your release?

No. No. What of this sentence?! [...] I can’t imagine it - I don't know where I am going to be. I don't know what is going to happen [...] My parole is in 2036 - the world is going to be crazy then - I don't even want to think about that.

Damien, early twenties, 27-year tariff, Early

Concerns about time were not just centred on the 'self', but extended to relational issues, particularly thoughts about loved ones left behind in the aftermath of their conviction. Most commonly, when reflecting on the time that would have to serve, interviewees expressed profound concerns regarding the wellbeing of family members and fears that loved ones might die during their sentence:

I just kept thinking "20 years?!" And I kept thinking too much ahead on the same day I got sentenced - "How am I - how long I'm going to be [here]? How is it going to be like when I get out? And how is my family going to survive?” It was too, too much questions and no answers.

Aakif, early twenties, 19-year tariff, Early 
My mum might die today, my grandma tomorrow, anyone could go. Who knows!

That's what I am saying. That's certain stuff that I can't take as well, losing people on the outside, I can't take it.

Damien, early twenties, 27-year tariff, Early

For those interviewees with children, a particularly painful aspect of temporal vertigo was the consideration of one's sentence in relation to the age of one's own children. For example, Liz (early twenties, 15-year tariff, Early) talked at length about how 'hard' it was thinking about 'time left to serve' in relation to the lost years of her son's life, who was eight years old at the time of interview, and would be in his twenties when Liz reached her tariff date.

The offence-time nexus relating to serving such long sentences from young adulthood - when the children of interviewees were generally very young - was also identified as resulting in the loss of the core joys and privileges of being a parent; this was identified as an acutely painful experience by both mothers and fathers:

Because my little girl was less than a year old when I came to prison, I missed her first steps, I missed her first words, and I missed like all of the firsts, and it's, like, that's quite difficult.

Catherine, early twenties, 22-year tariff, Early

Early-stage interviewees who did not have children prior to incarceration expressed deep concerns about the ability to be a 'full' parent upon release, hinting at anxieties about their own mortality:

[Having children] feels possible, but it feels - like, I'm going to be old, like in my late thirties? And I'm having a kid? So, when the kid's 10, I'm going to be nearly 50?! So basically, I can't run in the park with him - I'll be all old.

James, early twenties, 22-tear tariff, Early

If I get out, I'll be 47 - I'm not going to want a child at that age, do you know what I mean? My baby will probably be - my baby would be 10 and I'll be like 57 and dying or something $[\ldots]$ What's so fun about that? 
As also identified by Walker and Worrall (2000:28), concerns with the loss of 'control over fertility' and the possibilities of future parenthood were particularly painful for women. Those women who talked about their intention to have children upon release noted the young age at which they had started their current sentence. This temporal aspect of the experience enabled them to offset concerns such as those expressed by James and Tamara above:

I will have an opportunity to have children and start over again because I've got this [sentence] out of the way earlier.

Liz, early twenties, 15-year tariff, Early

Others, though, saw the long-term and indeterminate nature of their sentence as representing the death knell of their fertility:

I've resigned myself that that's never gonna happen [...] And that's my one regret - not having children.

Tori, early thirties, 15-year tariff, Late

\section{'Intrusive recollections'}

Intrusive recollections - repeated and vivid flash-backs, nightmares, and unwanted thoughts regarding a specific event - have long been recognised as symptomatic of the experience of trauma, representing one of the key diagnostic criteria for post-traumatic stress disorder (PTSD) (Cramer, 2000). Such recollections are termed 'intrusive' because they are involuntary and 'unwanted' to those who experience them; in this respect, they are distinct from voluntary ruminations on an event (Hackmann, Ehlers, Speckens \& Clark, 2000). The experience of intrusive recollections, and of PTSD more broadly, has been repeatedly identified in relation to the trauma of crime victimisation (e.g. Barker-Collo, Melnyk \& McDonald-Miszczak, 2000). Less common, however, are studies linking offence-induced trauma to the perpetrator, who may also experience shock, disbelief, and invasive recollections following their own act of killing or of witnessing a murder: 
[V]ivid images of and detailed flashbacks to the crime scene, distressing dreams of the event, [and] avoidance of stimuli remind the perpetrator of the killing [...] The perpetrator's reaction may, therefore, resemble the typical pattern of psychological responses to an isolated, overwhelming and traumatic experience.

(Pollock, 2000:177)

Many interviewees reported a similar narrative - to borrow Meichenbaum's (1996, cit. in Pollock, 2000:177) phrase regarding the impact of traumatic events - of the killing being 'indelibly etched on the individual's mind',, and of being repeatedly re-experienced through flashbacks and nightmares: ${ }^{7}$

For months afterwards [...] I tried to distance myself from it but my body wouldn't let me forget because of the bloody nightmares. Like night terrors?

Karen, late twenties, 20-year tariff, Mid

I get visions of her face sometimes in my dreams [...] It's horrible.

Laura, late twenties, 18-year tariff, Early

I'm suffering flashbacks [...] from the event what happened. I pray to god every day that it goes away - I don't want it to be with me for the rest of my life.

Zufar, early twenties, 25-year tariff, Early

Despite the prevalence of such narratives, interviewees repeatedly stated that little support was available for them to deal with such recollections, particularly during the early years of their sentence, when they were most frequent and intense. Some late-phase interviewees reported having received no psychological or psychiatric support for their experiences at all: one female interviewee, for example, had served more than 20 years, and yet had "never had counselling for the fact that [she had] watched two brutal murders". Although the idea that homicide perpetrators might be traumatised by their own actions might seem perverse or 'surprising' (cf. Pollock, 2000), it was evident that the commission or witnessing of a murder could result in a deeply 'traumatic psychological response', of the type identified by Pollock (2000:177). How our interviewees reacted to - and ultimately, defended against - such experiences, and to the

\footnotetext{
${ }^{7}$ Flashbacks and recollections were often triggered by temporal cues, such as an anniversary of the offence, or by physical cues, such as specific smells, sights or sounds.
} 
feelings of entry shock and temporal vertigo that we have thus far highlighted, is the subject of the remainder of this article.

\section{Modes of adjustment}

According to O'Donnell (2014:222), the primary concern of the prisoner in solitary confinement is 'taming time', and 'reframing' the isolation inherent in their predicament. For individuals in our sample, often serving minimum sentences longer than they had been alive, mastering some sense of both the present and the future - 'doing the sentence', rather than letting the sentence 'do them' - was a central concern. Many prisoners talked of the basic necessity of 'survival', and of the fact that they had no option but to 'cope' with what seemed like an un-survivable situation. More than this, however, our interviewees also had to contend with reconciling themselves with the offence for which they had been convicted (i.e. murder), whether or not they considered themselves to be guilty. This dual psychological burden, involving a particular combination of time to be served alongside the burden of an extreme offence, generated three primary patterns of response: suppression, denial, and sublimation.

\section{'Suppression'}

Suppression represents an important and high adaptive psychic defence mechanism (Cramer, 2000). Like its less 'mature" ${ }^{8}$ cousin 'repression', suppression also enables the minimisation of painful affects and realities. Unlike the former - whereby all conscious awareness of conflict and painful realities is banished; 'disguised' and 'ignored' - suppression involves 'far more than a simple neglect or repression of reality' (Valliant, 1994:45). Instead, it represents a form of mental cognisance which enabled the pains of early imprisonment to be acknowledged at certain times, and suppressed at others. This ability was identified within interviewees' narratives as crucial to surviving the early years of the sentence:

I just try and block a lot of things out, me [...] If it's too stressful to think about, I just don't think about it.

Liz, early twenties, 15-year tariff, Early

\footnotetext{
${ }^{8}$ Within the current context, the terms maturity and immaturity refer specifically to their use within clinical psychiatry as developmental indicators of the 'adequacy' of an individual's 'interpersonal and global functioning' (Cramer, 2000:642). 'Defence mechanisms' are hierarchically arranged, with the most 'mature' [i.e. high adaptive] at the top, and the least 'mature' [i.e. low adaptive] at the bottom (Cramer, 2000).

9 'Repression' does not represent a defence mechanism per se, as if simply - and successfully - 'blotting' out of the conscious mind the painful reality in question were so easily and effectively achieved, 'then there would be no need for defence mechanisms' (Baumeister, Dale \& Sommer, 1998:1084-5).
} 
The less aware you are, the easier it is to deal with, innit? [...][B]lank nothingness that's what gets you through. And if you can put yourself in that kind of state, that's how you survive.

Neil, early thirties, 18-year tariff, Mid

Such techniques of avoidance were often acknowledged as a deliberate and pro-active means of trying to escape from, for instance, intrusive recollections of the index offence. For those who could not rely on the power of the mind alone to block out 'unwanted thoughts', suppression was also achieved through the use of narcotics (both prescription and illicit) and alcohol. Identified as a popular means of 'seeking refuge' from the impact of time (Toch \& Adams, 1989; see also Cope, 2003), the pursuit of chemical oblivion served to bypass or accelerate the early period of confinement by consciously and 'forcibly ejecting unwanted thoughts from the conscious mind' (Baumeister et al, 1998:1085):

The whole point of taking heroin became that I didn't [have to] think about a minute [of the sentence], really.

Phillip, late thirties, 16-year tariff, Mid

I'd say the first five years are the hardest, because you're coming to terms with your sentence [...] Going home was just - it was too far away. But I got through it. I survived it. I dragged myself through with whatever means was available really.

Yvette, early thirties, 15-year tariff, Mid

For some interviewees, however, the need to escape principally reflected the "sheer boredom" of being a long-term prisoner. Again, substance use provided a means for achieving this, facilitating escape through sleep, which represented another means of cheating temporality:

When I first come in, I was on Category A, so, you're [...] locked up in your cell for 23 hours a day [...] In the early stages you don't even know what you do. Just sleep. Do a hell of a lot of sleeping [...] I was just messing about, taking drugs and things, drinking and that [because of the] sheer boredom. That's all it's about, nothing else - escapism, getting out that cell [...] Just makes you feel good for a bit. 
While such patterns of adjustment have more been presented as maladaptive within prison sociology (although see Toch \& Adams, 1989), suppression has long been considered as evidence of 'high adaptive' and 'mature' coping within the field of psychiatry (Cramer, 2000). While we do not seek to judge the veracity of either discipline's claim, suppression was clearly represented by our participants as a useful defensive means for doing so.

\section{'Denial'}

One of Freud's original 'defence mechanisms of the ego', 'painful' claims from the external world can be managed through denial; that is, 'ward[ed] off' by ignoring or disavowing their very existence (Modell, 1961:533). This, Cramer (2000) suggests, is a less 'mature' defence than the conscious postponement of pain through suppression or the 'creative' pro-activity of sublimation. Denial is distinct from these 'high adaptive' defences because of its unexpurgated refusal to acknowledge the existence of the problematic reality at hand. In the current context, suppression does not deny the external reality of the sentence or offence, but postpones the point at which they are considered; conversely, denial involves unequivocally disputing (rather than accepting) problematic elements of the external reality (e.g. commission of the offence, or the legitimacy of the sentence).

While sometimes referring to outright abjuration of the commission of a specific offence, denial is more appropriately acknowledged as existing on a 'continuum' of behaviours (Levenson \& Macgowan, 2004:52; Cohen, 2001:xi). Here, we focus on two specific states of denial, centred on the offence-time nexus: i.e. the first relates to the offence itself, and the second to time and the sentence. Both positions - which sometimes occurred alongside each other, and at other times appeared quite separate projects - provided individuals with a means of adjusting to the most troubling aspects of their new reality by re-focusing the finality and temporality of their predicament, as well as contesting notions of legal and moral guilt.

Denial of the offence was a defence mechanism that seemed to hold at bay the painful realities entailed by a conviction for murder. Much like the terminally ill patient denying the reality of their diagnosis (cf. Kübler-Ross, 1969/1997:51), denial of the offence 'function[ed] as a buffer' between the prisoner and the 'uncomfortable and painful situation' of having taken a human life. As Mathiassen (2016:3) also identified, the self-recognition of the capability to kill caused in some interviewees a deep sense of 'mourning' - both for their lives, and the lives 
they had caused to end - and fractured their self-perceptions. This resulted in the painful quest to reconcile their own sense of 'self' with that of an individual 'capable of taking another person's life' (cf. Mathiassen, 2016:3):

I didn't wanna have to accept that I took a human life [...] I couldn't believe I could be that person? So it took a long time for me to actually fully accept that no matter what way I look at it, I did take someone's life.

John, late twenties, 15-year tariff, Mid

As such, some described coming to terms with the sentence length as almost immaterial in comparison to the task of coming to terms with the implications of committing a murder, as one mid-sentence interviewee reflected:

Coming to terms with your sentence, you do that pretty early, innit? It's something that you have to do? [...] But coming to terms with what you've done is a completely different ballgame. And I don't think it really happens in that first stage. Not for me anyway. It took me a long time to realise.

Asad, early thirties, 18-year tariff, Mid

For some, the implications of this realisation was a deep self-loathing, and a sense of not deserving to live while their victim was unable to do the same, and such perceptions could result in a bleak existential 'nothingness', leaving individuals disinclined to direct themselves towards the future (Mathiassen, 2016).

While it is true that for some coming to terms with the sentence was a comparatively easy project when measured against coming to terms with the offence, the length of prison time they were facing also represented a cause for defensive denial. Denial of time and the sentence helped interviewees to cope with temporal frameworks which lay outside their coping capacities by allowing them to dispute the existence of time, rather than seeking to wipe out their conscious acknowledgment of it. For those struggling to adjust to the length of their sentence in the initial period of confinement, denial of the permanence of their new reality offered hope and 'light' in the darkness and pain of the early stage: 
I was in denial for a while [...] I was just thinking ... 'I'll get out soon possibly' [...] I was looking for the light at the end of the tunnel.

Dean, late teens, 16-year tariff, Early

Cohen and Taylor (1972:92) argue that 'obsessively thinking' about the future time to be served is 'a near certain way of doing hard time'. For many interviewees, denying time - either by focussing on the immediate present, or refusing to consider the sentence in its temporal entirety - made the sentence more manageable:

I just take each day as it comes because if you start thinking too far ahead, then it's a lot harder ... it is a lot harder if you take it in too big a chunk.

Carl, early twenties, 25-year tariff, Early

[T] here are days when it consumes you, and there is no way that I could take it more than one day at a time. Because, at the moment, I don't see a future and I don't see a life. Maria, early twenties, 20+ years' tariff, Early

Those who did consider the entire span of their sentence devised strategies for segmenting time, breaking it down into more manageable and meaningful chunks (see O'Donnell 2014), for example, through a timetable of major sporting tournaments, such as a series of World Cups (held four years apart), or into the years it would take to progress through various security categories:

I'll have another 3 or 4 years here. Then there will be close to 20 left. Then I'll be Cat $\mathrm{B}$, and before you know it, you're in D Cat and you can go home.

Terrance, mid-twenties, 28-year tariff, Early

Even where such methods appeared as a form of guileless optimism, breezily talking away the decades ahead, it was clear that they provided feelings of control or mastery over the time.

Yet just as it was impossible to disentangle the key components of entry shock from one another, so denial of time, denial of the sentence and denial of the offence were bound up with one another, particularly as the latter could offer an element of 'hope' for evading the former: 
The shock of being in prison and knowing that I'm doing 18 years - I couldn't see that far into the future [...] I couldn't picture myself doing 18 years. I thought, 'Well, I can't escape [from prison]', and at first I was denying the offence, thinking about 'Maybe I can get out on appeal?' It's like you're grasping for hope.

Alan, early thirties, 18-year tariff, Mid

However, the pro-active nature of appealing a conviction or sentence demarcates it from pure re-active denial and pushes it into the realm of sublimation, as discussed below.

Taking a life represented not simply an assault on the perceptions that individuals had previously held about themselves (cf. Pollock, 2000), but also those held about them by others. In this sense, denial of the offence enabled early-stage prisoners to retain support of family and friends who may otherwise have abandoned them, as well as sidestepping or diminishing the deep personal 'guilt, remorse [and] shame' associated with 'being a murderer' (Ferrito et al, 2012:329). Again, this was often recognised as a feature of early-stage behaviour only by those interviewees who were reflecting back on this period, after many years of imprisonment:

When I got arrested I come up with a lie, basically - a bullshit story that I wasn't there? And I stuck with that story. I couldn't change it cos I knew that if I had changed it, it would look bad upon me [...] I was scared of rejection from my family.

Curtis, late twenties, 19-year tariff, Mid

My mother put me in a very awkward position [...] She said "You know, if I find out that you've done this, I will disown you". And so I had to adopt a denial stance on it.

Ray, early fifties, 15-year tariff, served 35+ years

None of this is to suggest that offence denial was either disingenuous or represented a misrepresentation of the truth. There is good reason to believe that some interviewees who contested the legitimacy of their conviction did so not because they were 'in denial', but because they did not personally commit the act of murder for which they were convicted. ${ }^{10}$

\footnotetext{
${ }^{10}$ Such individuals had often received convictions in accordance with the common law of Joint Enterprise; a form of secondary legal liability which Crewe, Liebling, Virgo and Padfield (2015) argue is 'an unfair and unclear' doctrine, being ambiguous in nature and perceptibly illegitimate in its application. Such feelings of illegitimacy were borne out in the current study, where almost three-quarters of the men ( 74 per cent) and half of the women (50 per cent) convicted in accordance with Joint Enterprise felt that they were not guilty of the specific crime of
} 
Neither was the denial represented here the sort of 'deviant', 'unhealthy' or 'pathological'/maladaptive denial discussed by Strauss and colleagues (1990). Indeed, the psychic need to push away the type of realities facing these young men and women was completely understandable. As Crawley and Sparks (2006:72) note, 'to surrender oneself to the meaningless world of the prison as a life project must be truly terrible'.

\section{'Sublimation'}

Along with humour and suppression, sublimation has been identified as a mature, or high adaptive, behavioural response 'at times of crisis' (see e.g. Valliant, 1994:47; Cramer, 2000). While the original Freudian definition focused on defending against (intolerable) sexual instinct and urges (Baumeister et al, 1998), an expansive definition of sublimation engages with the ways in which people cope with and respond more broadly to 'generally intolerable affects' (moods and emotional states) via 'self-satisfying and socially acceptable means' (Diehl, Chui, Hay, et al, 2014:34):

[W]ith sublimation, instincts are channelled rather than dammed or diverted. Successful artistic expression remains the classic example [...] [F] eelings are acknowledged, modified, and directed toward a relatively significant [...] goal.

(Valliant, 1971:118) (emphasis added)

It is this goal-centred and self-satisfying nature of sublimation, along with the focus on 'artistic or intellectual endeavors' (Baumeister et al, 1998:1103), which distinguishes it in the literature from the socially unacceptable, oblivion-oriented defence of substance use (suppression), or the 'relatively pathological' and inactive response of denial (cf. Valliant, 1971:109).

For some interviewees, then, instead of defending against their feelings of sadness, guilt, and despair via suppression or denial, their reaction represented a channelling of these emotions into positive and intellectual endeavours. Often, this represented a symbolic act of claiming back part of the life they had hoped for prior to coming to prison:

murder. Many identified themselves as guilty of an offence - for example, manslaughter or perverting the course of justice - but (as a 'secondary offender') not one that warranted the same punishment as the 'primary offender'/main protagonist (Hulley, Crewe \& Wright, 2015). 
I want to be able to do a degree while I'm in here. Because it would be a shame for me, personally, to have come so close to going to uni [prior to conviction] and then deciding I'll never go [...] If I've got that potential, then I might as well see fit to put good use to it.

Carl, early twenties, 25-year tariff, Early

\begin{abstract}
Along with such intellectual endeavours, other 'socially acceptable' (cf. Diehl et al, 2014) sublimations involved pseudo-legal activity, for example sifting through case papers, looking for "loopholes" to challenge a conviction, and launching formal appeals. Such pro-active behaviour, which actively challenged rather than simply denied the predicament, offered 'lifers' a means of "giving themselves hope" [Asad, early thirties, 18-year tariff, Mid]. Again, it is this active element which separates sublimation from denial.

Reflecting back, interviewees further into their sentence described how channelling their energy into an appeal was a crucial "coping mechanism" in the early years:
\end{abstract}

\title{
At what point did you appeal?
}

Straightaway [...] Like you do. Every lifer up and down the country does the same thing. For the first 10 years [...] [appealing] is another coping mechanism to get you through.

Roger, early forties, 20-year tariff, served 20+ years

I appealed both [sentence and conviction] [...] I think it's just a bid for freedom. You know, like, in the olden days people used to escape. And nowadays there's none of that, [appealing is] just a natural thing to do.

Willis, late thirties, 19-year tariff, Mid

It is this channelling of the 'intolerable' pains of long-term imprisonment into direct and positive action, and 'socially acceptable' forms, which distinguishes sublimation from suppression (the means of which are not necessarily 'socially acceptable') and denial (the character of which is seldom concerned with 'action', 'goal-orientated' or otherwise). 


\section{Concluding thoughts}

The frameworks used for making sense of the processes by which prisoners react and adapt to the experience of confinement have tended to be sociological or psychological, neglecting the possibility that psychoanalytic concepts might be of value in understanding how prisoners make sense of and manage what they are forced to undergo. Given that Sykes, in his classic (1958/2007) account of the pains of imprisonment, makes frequent reference to psychoanalytic concepts - 'latent' sexual tendencies (p.71), 'feelings at [both] the conscious and unconscious level' (p.71); 'ego image' (p.72); 'Super-Ego' (p.73) - the absence of such concepts from mainstream penological analysis is all the more notable. The prisoner, Sykes notes, must defend against threats to his [sic] self-conception: 'Rejection or degradation by the free community must be warded off, turned aside, rendered harmless' (p.67). While we make no claims to have employed Freudian terminology in an orthodox sense, our argument in this paper is that they are of particular relevance to a population which is forced to confront an especially extreme set of circumstances: both the commission of murder, and the prospect of an exceptionally long period of custody, starting at a point in life when adulthood has barely begun. While we did not set out to explore the psychic implications of either part of this Offence-Time Nexus, their relevance to the early stage of the sentence was especially apparent.

It is for further articles (Crewe, Hulley \& Wright, under review) to explore how our population progressed through the sentence, and for other scholars to see whether the kind of framework that we have adopted here might be pertinent to other kinds of prisoners serving other kinds of sentences.

\section{Funding information}

We are grateful for the support of by the Economic and Social Research Council [grant: ES/J007935/1], and the Isaac Newton Trust.

\section{References}

Adshead, G., Ferrito, M., \& Bose, S. (2015). Recovery after homicide: Narrative shifts in therapy with homicide perpetrators. Criminal Justice \& Behavior, 42(1), 70-81.

Banister, P., Smith, F., Heskin, K., \& Bolton, N. (1973). Psychological correlates of long-term imprisonment. The British Journal of Criminology, 13(4), 312-330. 
Barker-Collo, S., Melnyk, W., \& McDonald-Miszczak, L. (2000). A cognitive-behavioral model of post-traumatic stress for sexually abused females. Journal of Interpersonal Violence, 15(4), 375-392.

Baumeister, R., Dale, K., \& Sommer, K. (1998). Freudian defense mechanisms and empirical findings in modern social psychology: Reaction formation, projection, displacement, undoing, isolation, sublimation, and denial. Journal of Personality, 66(6), 1081-1124.

Bottoms, A., \& Light, R. (1987). Problems of long-term imprisonment. Aldershot: Gower.

Clemmer, D. (1940/1958). The prison community. New York: Holt, Rinehart \& Winston.

Cohen, S. (2001). States of denial: Knowing about atrocities and suffering. Cambridge: Polity Press.

Cohen, S., \& Taylor, L. (1972). Psychological survival. Harmondsworth: Penguin.

Cope, N. (2003). 'It's no time or high time': Young offenders' rxperiences of time and drug use in prison. The Howard Journal of Criminal Justice., 42(2), 158-175.

Cramer, P. (2000). Defense mechanisms in psychology today. Further processes for adaptation. The American Psychologist, 55(6), 637-646.

Crawley, E., \& Sparks, R. (2006). Is there life after imprisonment? How elderly men talk about imprisonment and release. Criminology and Criminal Justice, 6(1), 63-82.

Crewe, B. (2009). The prisoner society: Power, adaptation, and social life in an English prison. Oxford: Oxford University Press.

Crewe, B., Hulley, S. and Wright, S. (under review). 'Re-conceptualising 'life': Adapting to long term imprisonment'.

Crewe, B., Hulley, S. and Wright, S. (in progress). 'The gendered pains of long life imprisonment'.

Diehl, M., Chui, H., Hay, E., \& al, e. (2014). Change in coping and defense mechanisms across adulthood: Longitudinal findings in a European-American sample. Developmental Psychology, 50(2), 634-48.

Feeny, N., Zoellner, L., Fitzgibbons, L., \& Foa, E. (2000). Exploring the roles of emotional numbing, depression, and dissociation in PTSD. Journal of Traumatic Stress, 13(3), 489-498.

Ferrito, M., Vetere, A., Adshead, G., \& Moore, E. (2012). Life after homicide: Accounts of recovery and redemption ofoffender patients in a high security hospital - A qualitative study. The Journal of Forensic Psychiatry \& Psychology, 23, 327-344. 
Flanagan, T. J. (1981). Dealing with long-term confinement: Adaptive strategies and perspectives among long-term prisoners. Criminal Justice \& Behavior, 8, 201-222.

Freud, A. (1937/1993). The ego and the mechanisms of defence. (C. Baines, Trans.) London: Karnac Books Ltd.

Hackmann, A., Ehlers, A., Speckens, A., \& Clark, D. M. (2004). Characteristics and content of intrusive memories in PTSD and their changes with treatment. Journal of Traumatic Stress., 17(3), 231-240.

Haney, C. (2001). The psychological impact of incarceration - Implications for post-prison adjustment. NAtional Policy Conference - From Prison to Home: The Effect of Incarceration and Reentry onChildren, Families and Communities (pp. 1-19). Washington D.C.: U.S. Department of Health and Human Services.

Haney, C., \& Lynch, M. (1997). Regulating prisons of the future: A psychological analysis of supermax and solitary confinment. New York University Review of Law \& Social Change, XXIII, 477-571.

Hartnagel, T., \& Gillan, M. (1980). Female prisoners and the inmate code. Sociological Perspectives, 23(1), 85-104.

Heffernan, E. (1972). Making it in prison: The square, the cool, and the life. New York: Wiley. Hollway, W., \& Jefferson, T. (2000). Doing qualitative research differently: Free association, narrative and the interview method. . London: Sage Publications.

Home Office. (1968). Advisory Council on the Penal System. The regime for long-term prisoners under conditions of maximum security. London: HMSO.

Hulley, S., Crewe, B. and Wright, S. (2015). Re-examining the problems of long-term imprisonment. British Journal of Criminology. Published online 5 August 2015:

doi:10.1093/bjc/azv077.

Irwin, J. (1987/1970). The Felon. Berkeley: University of California Press.

James, E. (2013, July 7). Hope for a prison lifer is exhausting. The Guardian. Retrieved October 22, 2014, from http://www.theguardian.com/commentisfree/2013/jul/07/hopeprison-lifer-exhausting-sentence

Jewkes, Y. (2005). Loss, liminality, and the life sentence: Managing identity through a disrupted lifecourse. In A. Liebling, \& S. Maruna, The effects of imprisonment (pp. 366388). Cullompton: Willan.

Jose-Kampfner, C. (1990). Coming to terms with existential death: An analysis of women's adaptation to life in prison. Social Justice, 17(2), 110-125. 
Kübler-Ross, E. (1969/1997). On death and dying. New York, USA: Scribner.

Levenson, J., \& Macgowan, M. (2004). Engagement, denial, and treatment progress among sex offenders in group therapy. Sexual Abuse: A Journal of Research and Treatment, 16(1), 49-63.

Liebling, A. (1999). Prison suicide and prisoner coping. Crime \& Justice, 283-359.

Liebling, A., \& Maruna, S. (2005). Introduction: The effects of imprisonment revisited. In A. Liebling, \& S. Maruna, The effects of imprisonment (pp. 1-29). Cullompton: Willan Publishing.

MacKenzie, D., \& Goodstein, L. (1985). Long-term incarceration impacts and characteristics of long-Term offenders: An empirical analysis. Criminal Justice \& Behavior, 12(4), 395-414.

MacKenzie, D., Robinson, J., \& Campbell, C. (1989). Long-term incarceration of female offenders: Prison adjustment and coping. Criminal Justice \& Behavior, 16(2), 223-238.

Mathiassen, C. (2016). Nothingness: Imprisoned in existence, excluded from society. In. Bang, J. \& Winther-Lindqvist, D. (eds.) Nothingness. New Brunswick (US) \& London (UK): Transaction Publishers.

McAdams, D. (1988). Biography, narrative, and lives: An introduction. Journal of Personality, 56(1), 1-18.

Ministry of Justice. (2013). Prison Population Statistics [SN/SG/4334]. London: Ministry of Justice.

Modell, A. (1961). Denial and the sense of separateness. Journal of the American Psychoanalytic Association, 9, 533-547.

O'Donnell, I. (2014). Prisoners, Solitude, and Time. Oxford: Oxford University Press.

Pollock, P. (2000). Eye movement desensitization and reprocessing (EMDR) for post-traumatic stress disorder (PTSD) following homicide. The Journal of Forensic Psychiatry, 11(1), 176-184.

Richards, B. (1978). The experience of long-term imprisonment. British Journal of Criminology, 18(2), 162-169.

Santos, M. (1995). Facing long-term imprisonment. In T. Flanagan, Long-term imprisonment: Policy, science, and correctional practice (pp. 36-40). Thousand Oaks: Sage Publications Inc.

Sapsford, R. (1978). Life-sentence prisoners: Psychological changes during sentence. The British Journal of Criminology, 18(2), 128-145. 
Srivastava, P., \& Hopwood, N. (2009). A practical iterative framework for qualitative data analysis. International Journal of Qualitative Methods, 8(1), 76-84.

\begin{tabular}{|l|l|l|}
\hline & Interviewees - Male & Interviewees - Female \\
\hline
\end{tabular}

Strauss, D. H., Spitzer, R. L., \& Muskin, P. R. (1990). Maladaptive denial of physical illness: A proposal for DSM-IV. The American Journal of Psychiatry, 14(7), 1168-1172.

Sykes, G. (1958/2007). The society of captives: A study of a maximum security prison. New Jersey: Princeton University Press.

Toch, H., \& Adams, K. (1989). Coping: Maladaption in prisons. New Brunswick: Transaction Publishers.

Vaillant, G. (2000). Adaptive mental mechanisms: Their role in a positive psychology. American Psychologist, 55(1), 89-98.

Valliant, G. (1971). Theoretical hierarchy of adaptive ego mechanisms: A 30-year follow-up of 30 men selected for psychological health. Archives of General Psychiatry, 24(2), 107118.

Valliant, G. (1994). Ego mechanisms of defense and personality psychopathology. Journal of Abnormal Psychology, 103(1), 44-50.

Walker, S., \& Worrall, A. (2000). Life as a woman: The gendered pains of indeterminate imprisonment. Prison Service Journal, 132, 27-37.

Wormith, S. (1984). The controversy over the effects of long-term incarceration. Canadian Journal of Criminology, 26, 423-437.

Zamble, E. (1992). Behavior and adaptation in long-term prison inmates descriptive longitudinal results. Criminal Justice and Behavior, 19(4), 409-425.

Zamble, E., \& Porporino, F. (1988). Coping, behavior, and adaptation in prison inmates. New York: Springer-Verlag Publishing.

Table 1: Basic demographic data of the male and female interviewees in the current study 


\begin{tabular}{|c|c|c|}
\hline No. of prisons & 15 & 9 \\
\hline No. of participants & 126 & 21 \\
\hline Ethnicity & $\begin{array}{l}53.2 \% \text { - White } \\
30.2 \% \text { - Black } \\
8.8 \% \text { - Asian } \\
7.9 \% \text { - 'mixed race' } \\
0 \% \text { - 'other' }\end{array}$ & $\begin{array}{l}85.7 \% \text { - White } \\
4.8 \% \text { - Black } \\
0 \% \text { - Asian } \\
9.5 \% \text { - 'mixed race' } \\
0 \% \text { - 'other' }\end{array}$ \\
\hline Age range (in years) & $18-67$ & $20-45$ \\
\hline Mean age (in years) & 30 & 28 \\
\hline $\begin{array}{l}\text { Mean age (at time of } \\
\text { research) by sentence stage } \\
\text { (in years) }\end{array}$ & $\begin{array}{l}\text { Early }-22.3 \\
\text { Mid }-30.2 \\
\text { Late }-40.7 \\
\text { Late (over-tariff })-49.3 \\
-\end{array}$ & $\begin{array}{l}\text { Early }-23.4 \\
\text { Mid }-20.0 \\
\text { Late }-33.0 \\
\text { Late (over-tariff) }-42.0 \\
\text { Other }-35.5\end{array}$ \\
\hline Age sentenced (in years) & $13-25$ & $16-25$ \\
\hline $\begin{array}{l}\text { Mean age sentenced (in } \\
\text { years) }\end{array}$ & 20 & 20 \\
\hline $\begin{array}{l}\text { Mean age (at sentence) by } \\
\text { sentence stage (in years) }\end{array}$ & $\begin{array}{l}\text { Early }-19.5 \\
\text { Mid }-21.0 \\
\text { Late }-21.7 \\
\text { Late (over-tariff) }-20.9 \\
-\end{array}$ & $\begin{array}{l}\text { Early }-21.0 \\
\text { Mid }-19.8 \\
\text { Late }-18.5 \\
\text { Late (over- tariff) }-22.0 \\
\text { Other: } 21.5\end{array}$ \\
\hline Tariff range (in years) & $15-35$ & $15-25$ \\
\hline Mean tariff (in years) & 20 & 18.7 \\
\hline Time served & 10 months - 42 years & 10 months - 22 years \\
\hline Mean time served (in years) & 10 & 8 \\
\hline
\end{tabular}

